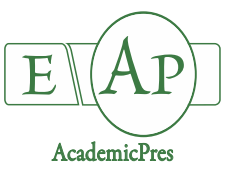

Becze A and Simedru D (2020)

Notulae Botanicae Horti Agrobotanici Cluj-Napoca 48(3):1426-1438

DOI: $10.15835 /$ nbha48312024

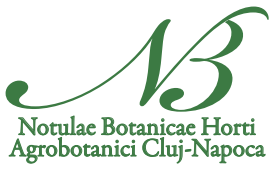

\title{
Rapid detection of walnut and pumpkin oil adulteration using Raman spectroscopy and partial least square methodology
}

\author{
Anca BECZE, Dorina SIMEDRU*
}

INCDO-INOE2000, Research Institute for Analytical Instrumentation, ICIA Cluj-Napoca Subsidiary, 400293 Cluj-Napoca,

Romania,icia@icia.ro ("corresponding author);dorina.simedru@icia.ro

\begin{abstract}
The purpose of this study is to develop a statistical method, based on Raman spectroscopy results, to quickly identify the adulteration of pumpkin and walnut oils. For this purpose, pure pumpkin and walnut oils from Cluj County, Romania were studied with Raman techniques. They were adulterated with sunflower oil at 14 levels of concentration, ranging from 2.5 to $50 \%$. The areas under the significant peaks were quantified and compared. A statistical method using the partial least square methodology was developed and used as a prediction tool in order to establish the adulteration percentage for pumpkin and walnut oils. 4 components were used to model the equation, the peak areas from $\sim 1264, \sim 1300, \sim 1441$ and respectively $\sim 1659 \mathrm{~cm}-1$. The final model equations take into account only the peak areas that had a high impact on the prediction values, statistically proven using the $\mathrm{p}$-value. The level of prediction obtained with the final model equation was $\geq$ $95 \%$.
\end{abstract}

Keywords: adulteration; partial least square methodology; Raman; pumpkin oil; walnut oils; spectroscopy; rapid detection

\section{Introduction}

Vegetable oils are liquid or solid fats extracted from seeds, cereal grains, nut and fruits with a composition based on a mixture of triacylglycerols, diacylglycerols, tocopherols, tocotrienols, phytosterols esters and phytosterols (Hammond, 2003). Vegetable oils can be traced back in time, starting with olive oil from 6000 BC in Israel (McMathis, 2015), palm and coconut oils from 4000 BC in Egypt (Roccisano et al., 2016) and soybean oil from $1000 \mathrm{AC}$ in China (https://www.soyinfocenter.com). Nowadays, they are intensively used in food processing, as fuel, in several home products and personal care products. Due to their wide usage, the global production has increased by approximately five times from 2007 to 2020 (https://www.statista.com).

In human consumption, vegetable oils are used for cooking, frying, in salads and as components of several types of processed foods. The consumption of vegetable oils is encouraged by the modern medicine which shows that the absorption of nutrients and vitamins depends on the functioning of hormonal processes and the consumption of fats (Conlon et al., 2012; Roccisano et al., 2016). Also, the fatty acids from vegetable oils have an important role in therapeutic and prophylactic prevention of many diseases, fetal neurological and reproductive development, optimal cardiovascular and endocrine functioning of adult humans and are now known to have anticancer potential (Hornstra et al., 1995; Breslow et al., 2006; Roccisano et al., 2016; Kumar 
et al., 2016). Compared with animal fats, the usage of vegetable oils in food manufacturing is considered to be a much healthier alternative then animal fats due to their higher content of unsaturated fatty acids (https://www.statista.com).

In recent years two new types of vegetable oils have received special attention due to their benefits for human health (Elfiky et al., 2012; Nederal et al., 2014; Nishimura et al., 2014; Seif, 2014; Abou-Zeid et al., 2018; Fawzy et al., 2018; Wong et al., 2019).

Pumpkin oil is obtained from pumpkin (Curcubita pepo L), a leafy green vegetable native from North America, but cultivated now also in Europe, Asia and Africa (Nederal et al., 2014; Nishimura et al., 2014). Pumpkin seeds are an important source of vitamins, fatty acids, various antioxidants, amino acids and fibres (Nishimura et al., 2014; Seif, 2014; Fawzy et al., 2018; Wong et al., 2019). Due to the composition of pumpkin seeds, pumpkin oil is used in human consumption for its nutritional value but was also tested in medicine as adjuvant treatment in: urinary dysfunction (Nishimura et al., 2014), protection against alcohol induced hepatotoxicity and oxidative stress (Seif, 2014), alleviation of the adverse effects of bisphenol A in human (Fawzy et al., 2018), reducing both brachial and central blood pressure as well as wave reflection in postmenopausal women with elevated blood pressure (Wong et al., 2019), protection against the cytotoxicity and genotoxicity induced by azathioprine (Elfiky et al., 2012), reducing the oxidative stress, apoptosis and toxic impacts on metabolizing enzymes gene expression induced by emamectin (Abou-Zeid et al., 2018).

Walnut oil is obtained from walnut tree (Juglans regia $\mathrm{L}$ ) which is, native from the mountain region of Central Asia and has become the most widespread tree nut in the world. According to the Food and Agriculture Organization over 1000000 metric tons of walnut oil are produced annually as follows: China (350000 tons), United States of America (210000 tons), Turkey (114000 tons), Iran (82000 tons), Europe (250000 tons) (http://www.fao.org). Walnut oil is composed mainly of polyunsaturated fatty acids (especially linoleic acid), tocopherols, proteins, minerals, phospholipids, sphingolipids, sterols, hydrocarbons and volatile compounds (Martínez et al., 2010; Rabadán et al., 2018). Its composition has important benefits on human health: it improves blood lipoprotein profile, shows anticancer and antiatherogenic effect, and contributes to the regulation of immunological activity and inflammatory response (Rabadán et al., 2018), has high antioxidant activity and can be considered as cancer chemo-preventive (Negi et al., 2011). Due to its high price, walnut oil is adulterated with cheaper edible oil such as soybean or sunflower oil ( $\mathrm{Li}$ et al., 2015).

The adulteration of edible oils is the process of adding cheaper and inferior oils that affect the quality of the product in order to reduce the fabrication costs. The adulterated oils can be a real threat to human health, such as the case of Spanish olive oil syndrome were nonedible rapeseed oil was sold as edible rapeseed oil and even as olive oil or the adulteration of mustard oil with poisonous argemone oil (Azadmard-Damirchi and Torbati, 2015). Nowadays, the adulteration of oils became more discreet so their values remain within the limits established by regulations (Azadmard-Damirchi and Torbati, 2015; Abbas and Baeten, 2016). In this situation it is imperative to develop sensitive analytical techniques to establish the purity of the oils. The most sensitive methods which were proposed are: nuclear magnetic resonance (NMR) (Hatzakis, 2013; Parker et al., 2014; Nam et al., 2014; Shi et al., 2018), near-infrared spectroscopy (NIR) (Chen et al., 2012; Farres et al., 2019; Yuan et al., 2020), FT-infrared spectroscopy (FT-IR) (Man et al., 2011; Man and Rohman, 2013) and Raman spectroscopy (Wei et al., 2013; Velioglu et al., 2016; Meenu et al., 2019). Raman spectroscopy is a quick and sensitive method which does not need any sample preparation in order to identify the adulteration of oils.

The purpose of this study is to develop quick and easy methods to determine the adulteration of pumpkin and walnut oils using portable Raman equipment and to create a pattern of behaviour of these oils when adulterated using the partial least squares (PLS) statistic method for the development of the model equation. 


\section{Materials and Methods}

\section{Sample collection and preparation}

Pure pumpkin, walnut and sunflower oils of Romanian provenience were acquired from producers of edibles oils from Cluj County. The pumpkin and walnut oils were adulterated with 14 levels of concentration of sunflower oil ranging from 2.5 to $50 \%$.

\section{Raman analysis}

All the oils were investigated with Rigaku PROGENY portable Raman using the following parameters: laser frequency: $1064 \mathrm{~nm}$; laser power: $200 \mathrm{~mW}$; exposure time: 10,000 ms; spectral range: 200-2000 cm-1. All Raman analyses were performed in triplicate at room temperature using $4 \mathrm{ml}$ of each sample.

\section{Data processing}

The raw data were processed using multiple peak function from Origin 8.5 (OriginLab, USA).

\section{Statistical analysis}

For statistical analysis the data were processed using Minitab 17 software. Partial least squares (PLS) regression was used to model the equation of adulterated oil concentration. To perform PLS, Minitab uses the nonlinear iterative partial least squares (NIPALS) algorithm developed by Herman Wold. The algorithm reduces the number of predictors using a technique similar to principal components analysis to extract a set of components that describes maximum correlation between the predictors and response variables (https://support.minitab.com).

\section{Validation of model}

The model equation was tested using adulterated oil samples to see if the degree of adulteration prediction is equal or higher than $95 \%$.

\section{Results}

Raman analysis

Raman spectra of investigated pumpkin, walnut and sunflower oils are presented in Figure 1.

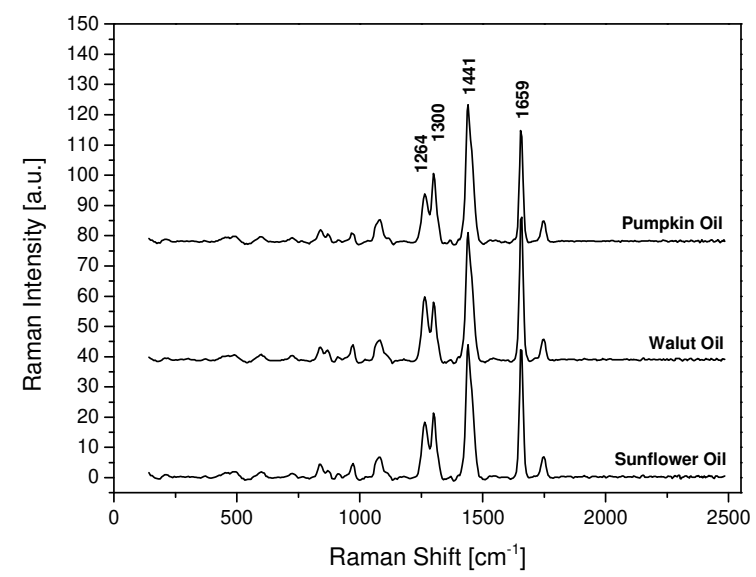

Figure 1. Raman spectra of investigated pumpkin, walnut and sunflower oils 
The obtained peaks and their assignments (Meenu et al., 2019) are presented in Table 1. The Raman peaks from $\sim 1659 \mathrm{~cm}^{-1}$ and $\sim 1264 \mathrm{~cm}^{-1}$ are assigned to vibration peaks of cis $(\mathrm{C}-\mathrm{C})$ and cis $(\mathrm{C}=\mathrm{H})$ of unsaturated fatty acids while the peaks from at $\sim 1441 \mathrm{~cm}^{-1}$ and $\sim 1300 \mathrm{~cm}^{-1}$ are assigned to scissoring vibrations and twisting vibrations of methylene (Li et al., 2018). Peak areas are presented in Table 2. For all investigated oils, the highest peak area is at $\sim 1441 \mathrm{~cm}^{-1}$ corresponding to scissoring vibrations of methylene. The lowest peak area is at $\sim 1264 \mathrm{~cm}^{-1}$ corresponding to vibration peaks of cis $(\mathrm{C}=\mathrm{H})$ of unsaturated fatty acid. Walnut and sunflower oils have the highest peak areas assigned to vibrations of unsaturated fatty acids groups while pumpkin oil have the highest peak areas assigned to vibrations of methylene groups.

Tabel 1. Main Raman peaks and their assignment (Li et al., 2018)

\begin{tabular}{|c|c|c|}
\hline No & Wavenumber $\left(\mathrm{cm}^{-}\right)$ & Assignment \\
\hline 1 & $\sim 1264$ & $\delta i p(=\mathrm{C}-\mathrm{H})$ Unconjugated cis $(\mathrm{RHC}=\mathrm{CHR})$ \\
\hline 2 & $\sim 1300$ & $\delta \gamma(\mathrm{C}-\mathrm{H})$ of Methylene $(\mathrm{CH} 2)$ \\
\hline 3 & $\sim 1441$ & $\delta \gamma(\mathrm{C}-\mathrm{H})$ of Methylene $(\mathrm{CH} 2)$ \\
\hline 4 & $\sim 1659$ & $\nu(\mathrm{C}=\mathrm{C})$ of unsaturated banding $(\mathrm{cis}$ RHC $=\mathrm{CHR})$ \\
\hline
\end{tabular}

Table 2. Peak areas of investigated pumpkin, walnut and sunflower oils

\begin{tabular}{|c|c|c|c|c|}
\hline \multirow{2}{*}{$\begin{array}{c}\text { Oil type/ Wavenumber } \\
\left(\mathrm{cm}^{-1}\right)\end{array}$} & $\sim 1264$ & $\sim 1300$ & $\sim 1441$ & $\sim 1659$ \\
\cline { 2 - 5 } & $468002 \pm 2.7 \%$ & $539749 \pm 4.1 \%$ & $1481990 \pm 5.1 \%$ & $664080 \pm 2.9 \%$ \\
\hline Pumpkin & $539254 \pm 3.5 \%$ & $506907 \pm 2.8 \%$ & $1425604 \pm 2.9 \%$ & $788539 \pm 2.8 \%$ \\
\hline Walnut & $539248 \pm 3.8 \%$ & $506911 \pm 3.7 \%$ & $1425610 \pm 3.8 \%$ & $788540 \pm 4.6 \%$ \\
\hline Sunflower
\end{tabular}

The peak areas of adulterated pumpkin and walnut oils are presented in Figure 2. For pumpkin oil a small decrease of $\sim 1659 \mathrm{~cm}^{-1}$ and $\sim 1264 \mathrm{~cm}^{-1}$ peak areas, an insignificant decrease of $\sim 1300 \mathrm{~cm}^{-1}$ peak area, and a significant decrease of $\sim 1441 \mathrm{~cm}^{-1}$ peak area could be observed. For walnut oil an increase of $\sim 1264 \mathrm{~cm}^{-1}$, $\sim 1300 \mathrm{~cm}^{-1}$ and $\sim 1441 \mathrm{~cm}^{-1}$ peak areas and an important decrease of $\sim 1659 \mathrm{~cm}^{-1}$ peak area could be observed.
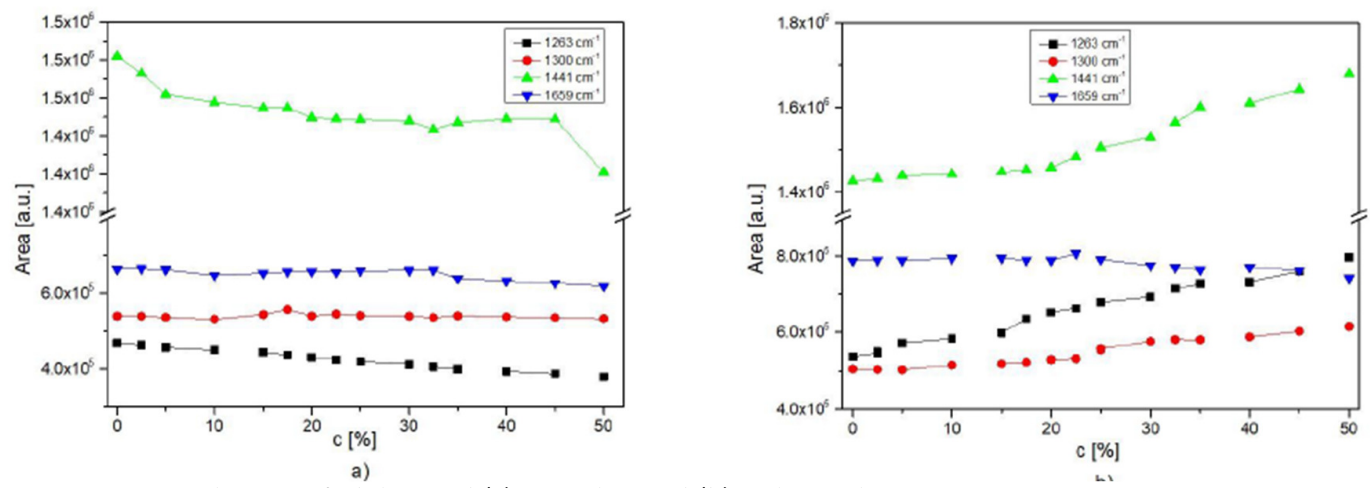

Figure 2. Peak areas of adulterated (a) pumpkin and (b) walnut oils

Although the data presented in Figure 2 show ascending or descending trends of pumpkin and walnut oils peaks varying together in line with the percentage of adulteration with sunflower oi, a conclusive behaviour cannot be drawn. A supplementary analysis of data is mandatory.

\section{Partial least squares (PLS) regression}

The peaks area of pumpkin and walnut oils obtained from Raman analysis for every level of adulteration are presented in Table 3. 
Table 3. Peaks area of pumpkin and walnut oils obtained from Raman analysis for the adulterated oils

\begin{tabular}{|c|c|c|c|c|c|c|c|c|}
\hline \multirow{3}{*}{$\begin{array}{c}\mathrm{c}(\%) / \\
\text { Wavenumber }\left(\mathrm{cm}^{-1}\right)\end{array}$} & \multicolumn{8}{|c|}{ Area [a.u.] } \\
\hline & \multicolumn{2}{|c|}{$\sim 1264$} & \multicolumn{2}{|c|}{$\sim 1300$} & \multicolumn{2}{|c|}{$\sim 1441$} & \multicolumn{2}{|c|}{$\sim 1659$} \\
\hline & $\mathrm{PO}$ & WO & $\mathrm{PO}$ & WO & $\mathrm{PO}$ & WO & $\mathrm{PO}$ & WO \\
\hline 0 & $\begin{array}{c}484806 \\
\pm 2.6 \%\end{array}$ & $\begin{array}{r}628959 \\
\pm 3.7 \%\end{array}$ & $\begin{array}{c}605008 \\
\pm 4.5 \%\end{array}$ & $\begin{array}{c}505902 \\
\pm 2.4 \%\end{array}$ & $\begin{array}{c}1581677 \\
\pm 5.4 \%\end{array}$ & $\begin{array}{c}1476560 \\
\pm 2.7 \%\end{array}$ & $\begin{array}{c}475263 \\
\pm 2.4\end{array}$ & $\begin{array}{c}606521 \\
\pm 2.7\end{array}$ \\
\hline 2.5 & $\begin{array}{c}484028 \\
\pm 2.9 \%\end{array}$ & $\begin{array}{c}631976 \\
\pm 3.0 \%\end{array}$ & $\begin{array}{l}601322 \\
\pm 4.3 \%\end{array}$ & $\begin{array}{c}507804 \\
\pm 2.4 \%\end{array}$ & $\begin{array}{c}1571197 \\
\pm 4.8 \%\end{array}$ & $\begin{array}{c}1478999 \\
\pm 2.9 \%\end{array}$ & $\begin{array}{c}475281 \\
\pm 2.9\end{array}$ & $\begin{array}{c}594085 \\
\pm 2.9\end{array}$ \\
\hline 5 & $\begin{array}{l}483740 \\
\pm 2.4 \%\end{array}$ & $\begin{array}{c}652526 \\
\pm 2.9 \%\end{array}$ & $\begin{array}{c}586626 \\
\pm 3.9 \%\end{array}$ & $\begin{array}{c}513614 \\
\pm 2.9 \%\end{array}$ & $\begin{array}{c}1574645 \\
\pm 5.1 \%\end{array}$ & $\begin{array}{c}1482811 \\
\pm 2.4\end{array}$ & $\begin{array}{c}470911 \\
\pm 3.1\end{array}$ & $\begin{array}{c}593807 \\
\pm 3.1\end{array}$ \\
\hline 10 & $\begin{array}{l}481608 \\
\pm 2.7 \% \\
\end{array}$ & $\begin{array}{r}658709 \\
\pm 2.7 \% \\
\end{array}$ & $\begin{array}{l}574388 \\
\pm 4.1 \% \\
\end{array}$ & $\begin{array}{r}519347 \\
\pm 3.1 \% \\
\end{array}$ & $\begin{array}{c}1544332 \\
\pm 5.0 \% \\
\end{array}$ & $\begin{array}{c}1482365 \\
\pm 2.1 \\
\end{array}$ & $\begin{array}{c}457473 \\
\pm 3.2 \\
\end{array}$ & $\begin{array}{c}590837 \\
\pm 2.7 \\
\end{array}$ \\
\hline 15 & $\begin{array}{c}480428 \\
\pm 2.4 \%\end{array}$ & $\begin{array}{l}668984 \\
\pm 2.6 \%\end{array}$ & $\begin{array}{l}580635 \\
\pm 3.9 \%\end{array}$ & $\begin{array}{l}523667 \\
\pm 3.2 \%\end{array}$ & $\begin{array}{c}1537402 \\
\pm 5.1 \%\end{array}$ & $\begin{array}{c}1484014 \\
\pm 2.8\end{array}$ & $\begin{array}{c}458978 \\
\pm 3.3\end{array}$ & $\begin{array}{c}585064 \\
\pm 3.1\end{array}$ \\
\hline 17.5 & $\begin{array}{l}478094 \\
\pm 2.6 \%\end{array}$ & $\begin{array}{c}702826 \\
\pm 2.5 \%\end{array}$ & $\begin{array}{c}588239 \\
\pm 4.5 \%\end{array}$ & $\begin{array}{c}528680 \\
\pm 3.3 \%\end{array}$ & $\begin{array}{c}1533784 \\
\pm 5.4 \%\end{array}$ & $\begin{array}{c}1485834 \\
\pm 3.1\end{array}$ & $\begin{array}{c}458760 \\
\pm 3.4\end{array}$ & $\begin{array}{c}574410 \\
\pm 3.2\end{array}$ \\
\hline 20 & $\begin{array}{l}476568 \\
\pm 2.4 \% \\
\end{array}$ & $\begin{array}{r}713699 \\
\pm 3.4 \% \\
\end{array}$ & $\begin{array}{l}563430 \\
\pm 4.2 \% \\
\end{array}$ & $\begin{array}{c}536984 \\
\pm 3.4 \% \\
\end{array}$ & $\begin{array}{c}1524396 \\
\pm 4.7 \% \\
\end{array}$ & $\begin{array}{c}1487071 \\
\pm 3.2 \\
\end{array}$ & $\begin{array}{c}457001 \\
\pm 3.1 \\
\end{array}$ & $\begin{array}{c}567783 \\
\pm 3.4 \\
\end{array}$ \\
\hline 22.5 & $\begin{array}{l}475330 \\
\pm 2.5 \%\end{array}$ & $\begin{array}{c}718866 \\
\pm 3.5 \%\end{array}$ & $\begin{array}{l}562304 \\
\pm 3.8 \%\end{array}$ & $\begin{array}{c}540892 \\
\pm 3.5 \%\end{array}$ & $\begin{array}{c}1519993 \\
\pm 3.9 \%\end{array}$ & $\begin{array}{c}1509810 \\
\pm 3.4\end{array}$ & $\begin{array}{c}452975 \\
\pm 2.9\end{array}$ & $\begin{array}{c}574354 \\
\pm 3.1\end{array}$ \\
\hline 25 & $\begin{array}{l}474667 \\
\pm 2.5 \% \\
\end{array}$ & $\begin{array}{r}732367 \\
\pm 3.1 \% \\
\end{array}$ & $\begin{array}{l}551986 \\
\pm 3.9 \% \\
\end{array}$ & $\begin{array}{r}565187 \\
\pm 3.6 \% \\
\end{array}$ & $\begin{array}{c}1515965 \\
\pm 3.9 \% \\
\end{array}$ & $\begin{array}{c}1529252 \\
\pm 2.9\end{array}$ & $\begin{array}{c}452975 \\
\pm 2.2 \\
\end{array}$ & $\begin{array}{c}557686 \\
\pm 3.2 \\
\end{array}$ \\
\hline 30 & $\begin{array}{c}472622 \\
\pm 2.7 \%\end{array}$ & $\begin{array}{c}739416 \\
\pm 3.2 \%\end{array}$ & $\begin{array}{c}544152 \\
\pm 4.1 \%\end{array}$ & $\begin{array}{l}585060 \\
\pm 3.7 \%\end{array}$ & $\begin{array}{c}1511493 \\
\pm 5.1 \%\end{array}$ & $\begin{array}{c}1550377 \\
\pm 2.1\end{array}$ & $\begin{array}{c}451071 \\
\pm 2.3\end{array}$ & $\begin{array}{c}540572 \\
\pm 3.1\end{array}$ \\
\hline 32.5 & $\begin{array}{l}470894 \\
\pm 2.9 \%\end{array}$ & $\begin{array}{c}756263 \\
\pm 2.7 \%\end{array}$ & $\begin{array}{c}538622 \\
\pm 4.2 \%\end{array}$ & $\begin{array}{c}591538 \\
\pm 3.1 \%\end{array}$ & $\begin{array}{c}1503129 \\
\pm 5.2 \%\end{array}$ & $\begin{array}{c}1581395 \\
\pm 2.3\end{array}$ & $\begin{array}{c}448950 \\
\pm 2.4\end{array}$ & $\begin{array}{c}531774 \\
\pm 2.4\end{array}$ \\
\hline 35 & $\begin{array}{r}469627 \\
\pm 2.8 \%\end{array}$ & $\begin{array}{c}761580 \\
\pm 2.6 \%\end{array}$ & $\begin{array}{l}537086 \\
\pm 4.3 \%\end{array}$ & $\begin{array}{r}592515 \\
\pm 3.8 \%\end{array}$ & $\begin{array}{c}1535934 \\
\pm 5.1 \%\end{array}$ & $\begin{array}{c}1614131 \\
\pm 2.9\end{array}$ & $\begin{array}{c}431776 \\
\pm 2.9\end{array}$ & $\begin{array}{c}521769 \\
\pm 2.1\end{array}$ \\
\hline 40 & $\begin{array}{l}468330 \\
\pm 2.5 \%\end{array}$ & $\begin{array}{l}759250 \\
\pm 2.5 \%\end{array}$ & $\begin{array}{c}528688 \\
+4.5 \%\end{array}$ & $\begin{array}{c}601539 \\
\pm 3.4 \%\end{array}$ & $\begin{array}{c}1501559 \\
\pm 4.7 \%\end{array}$ & $\begin{array}{c}1620210 \\
\pm 2.8\end{array}$ & $\begin{array}{c}424703 \\
\pm 2.5\end{array}$ & $\begin{array}{c}520859 \\
\pm 2.2\end{array}$ \\
\hline 45 & $\begin{array}{c}466314 \\
\pm 2.2 \% \\
\end{array}$ & $\begin{array}{r}780307 \\
\pm 3.4 \% \\
\end{array}$ & $\begin{array}{l}520982 \\
\pm 4.0 \% \\
\end{array}$ & $\begin{array}{r}617967 \\
\pm 3.7 \% \\
\end{array}$ & $\begin{array}{c}1497872 \\
\pm 4.3 \% \\
\end{array}$ & $\begin{array}{c}1649854 \\
\pm 2.5 \\
\end{array}$ & $\begin{array}{c}418682 \\
\pm 2.4\end{array}$ & $\begin{array}{c}510409 \\
\pm 2.3\end{array}$ \\
\hline 50 & $\begin{array}{l}462858 \\
\pm 2.3 \%\end{array}$ & $\begin{array}{c}810864 \\
\pm 3.5 \% \\
\end{array}$ & $\begin{array}{l}512917 \\
\pm 4.2 \% \\
\end{array}$ & $\begin{array}{l}632081 \\
\pm 3.9 \% \\
\end{array}$ & $\begin{array}{c}1456499 \\
\pm 4.1 \% \\
\end{array}$ & $\begin{array}{c}1682177 \\
\pm 2.1 \\
\end{array}$ & $\begin{array}{c}411283 \\
\pm 2.7 \\
\end{array}$ & $\begin{array}{c}491643 \\
\pm 2.7 \\
\end{array}$ \\
\hline $\begin{array}{c}\text { Linear correlation } \\
\text { coefficient }\end{array}$ & -0.996 & 0.985 & -0.976 & 0.979 & -0.925 & 0.938 & -0.961 & -0.981 \\
\hline
\end{tabular}

$1 \mathrm{PO}$ - pumpkin oil

$2 \mathrm{WO}$ - walnut oil

The linear correlation coefficient values were from -0.925 to -0.996 for the negate correlation and between 0.938 to 0.985 for the positive correlation which proves the strong connection between degrees of adulteration and the area at the selected wavelengths.

Four components where used to model the equation, the areas of the peaks at $\sim 1264 \mathrm{~cm}^{-1}, \sim 1300 \mathrm{~cm}^{-1}$, $\sim 1441 \mathrm{~cm}^{-1}$ and $\sim 1659 \mathrm{~cm}^{-1}$.

PLS for the walnut oil

Analysis of variance was applied on the data obtained for the walnut oil. The results are presented in Table 4. 
Table 4. Analysis of variance

\begin{tabular}{|c|c|c|c|c|c|}
\hline Source & DF & Adj SS & Adj MS & F-Value & P-Value \\
\hline Regression & 4 & 3284.11 & 821.027 & 166.80 & 0.000 \\
\hline$\sim 1264 \mathrm{~cm}^{-1}$ & 1 & 52.69 & 52.690 & 10.70 & 0.008 \\
\hline$\sim 1300 \mathrm{~cm}^{-1}$ & 1 & 3.00 & 2.999 & 0.61 & 0.453 \\
\hline$\sim 1441 \mathrm{~cm}^{-1}$ & 1 & 1.40 & 1.403 & 0.29 & 0.605 \\
\hline$\sim 1659 \mathrm{~cm}^{-1}$ & 1 & 0.14 & 0.137 & 0.03 & 0.871 \\
\hline Error & 10 & 49.22 & 4.922 & & \\
\hline Total & 14 & 3333.33 & & & \\
\hline
\end{tabular}

The degree of freedom (DF) represents the number of independent comparisons between the elements of an observation quantity or the number of values that can be chosen arbitrarily within a specification. It is used to estimate the values of unknown population parameters. Adjusted sums of squares (Adj SS) are measures of variation for different components of the model. Adjusted mean squares measure (Adj MS) how much variation a term or a model explains, assuming that all other terms are in the model, regardless of the order they were entered. Minitab uses the adjusted mean squares to calculate the p-value for a term (www.statsdirect.com; https://support.minitab.com; Dodge, 2010). The F-value is used to determine whether the term is associated with the response. Minitab uses the F-value to calculate the p-value, which is used to make a decision about the statistical significance of the terms and model. The P-value is equal to the area under the distribution curve, according to the statistical value of the test. The values should be lower than 0.05 . Lower p-values provide stronger evidence against the null hypothesis. For $\sim 1300 \mathrm{~cm}^{-1}, 1441 \mathrm{~cm}^{-1}$ and $\sim 1659 \mathrm{~cm}^{-1}$ the $\mathrm{p}$-value is high which means that they have little impact. For $\sim 1264 \mathrm{~cm}^{-1}$ the p-values is lower than $0.05,0.008$ respectively.

$\mathrm{R}$-sq is the percentage of variation in the response that is explained by the model. It is calculated as 1 minus the ratio of the error sum of squares to the total sum of squares. Thus, R-sq indicates how well a model fits the data. In order to vary the model, the R-sq was calculated. (Table 5). The closes R-sq of model is to $100 \%$, the better the fit between the input variables and the result. Predicted R-sq indicates how well each calculated model predicts the response. Predicted R-sq is calculated by systematically removing each observation from the data set, estimating the regression equation, and determining how well the model predicts the removed observation (https://support.minitab.com; Dodge, 2010).

Table 5. Model summary

\begin{tabular}{|c|c|c|c|}
\hline S & R-sq & R-sq (ad) & R-sq (pred) \\
\hline 2.21864 & $98.52 \%$ & $97.93 \%$ & $97.29 \%$ \\
\hline
\end{tabular}

The R-sq (pred) value for walnut oils is 97.29 , which means that the probability of the model predicting the write adulteration concentration is very high.

The correlation between the different variables for the adulteration of walnut oil is presented in Figure 3.

From the graphic (Figure 3) we can see that peaks at $\sim 1264 \mathrm{~cm}^{-1}, \sim 1300 \mathrm{~cm}^{-1}$ and $\sim 1441 \mathrm{~cm}^{-1}$ have a positive correlation with the adulteration concentration of walnut oil, while the peak at $\sim 1659 \mathrm{~cm}^{-1}$ has a negative correlation.

The regression equations for the adulteration of walnut oils are: Concentration $(\%)=$ $-163+0.000169 \cdot X 1+0.000081 \cdot X 2+0.000023 \cdot X 3-0.000027 \cdot X 4 \quad$ (1)

where:

$\mathrm{X} 1$ - peak area at $\sim 1264 \mathrm{~cm}^{-1}$

$\mathrm{X} 2$ - peak area at $\sim 1300 \mathrm{~cm}^{-1}$

$\mathrm{X} 3$ - peak area at $\sim 1441 \mathrm{~cm}^{-1}$

$\mathrm{X} 4$ - peak area at $\sim 1659 \mathrm{~cm}^{-1}$ 


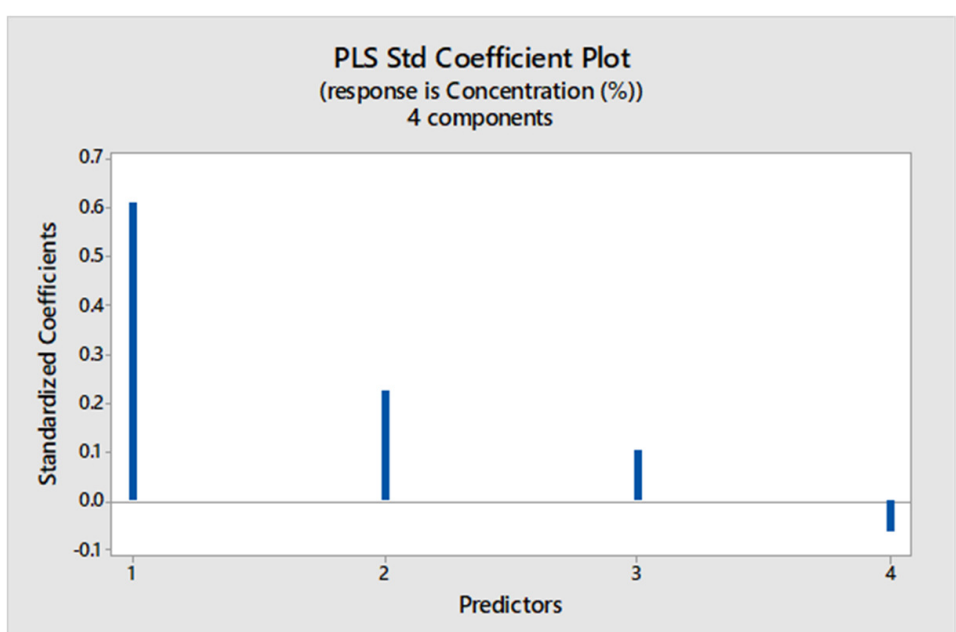

Figure 3. Projected scatterplot of the unstandardized regression coefficients for the adulteration of walnut oils

Figure 4 shows residual normal plot for the Raman analysis obtained for walnut oil. The points follow a straight line which proves that there are no unusual observations.

The final model equation does not contain all variables because the p-value has proven that some of them are not relevant. Figure 5 shows that $\sim 1264 \mathrm{~cm}^{-1}$ has the highest impact while, the peaks at $\sim 1441 \mathrm{~cm}^{-1}$ and $\sim 1659 \mathrm{~cm}^{-1}$ do not help to explain the additional variation of the adulteration concentration.

The final model equation is:

Wallnut oil adulteration $\%=-175.43+0.000164 \cdot X 1+0.000147 \cdot X 2(2)$ where:

$\mathrm{X} 1$ - peak area at $\sim 1264 \mathrm{~cm}^{-1}$

$\mathrm{X} 2$ - peak area at $\sim 1300 \mathrm{~cm}^{-1}$

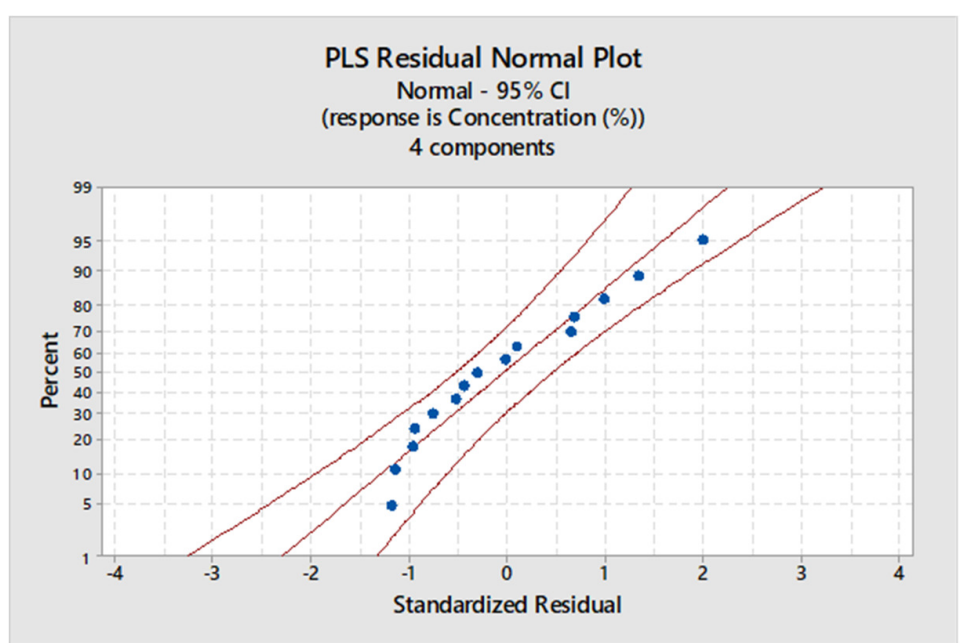

Figure 4. PLS residual for walnut oil 


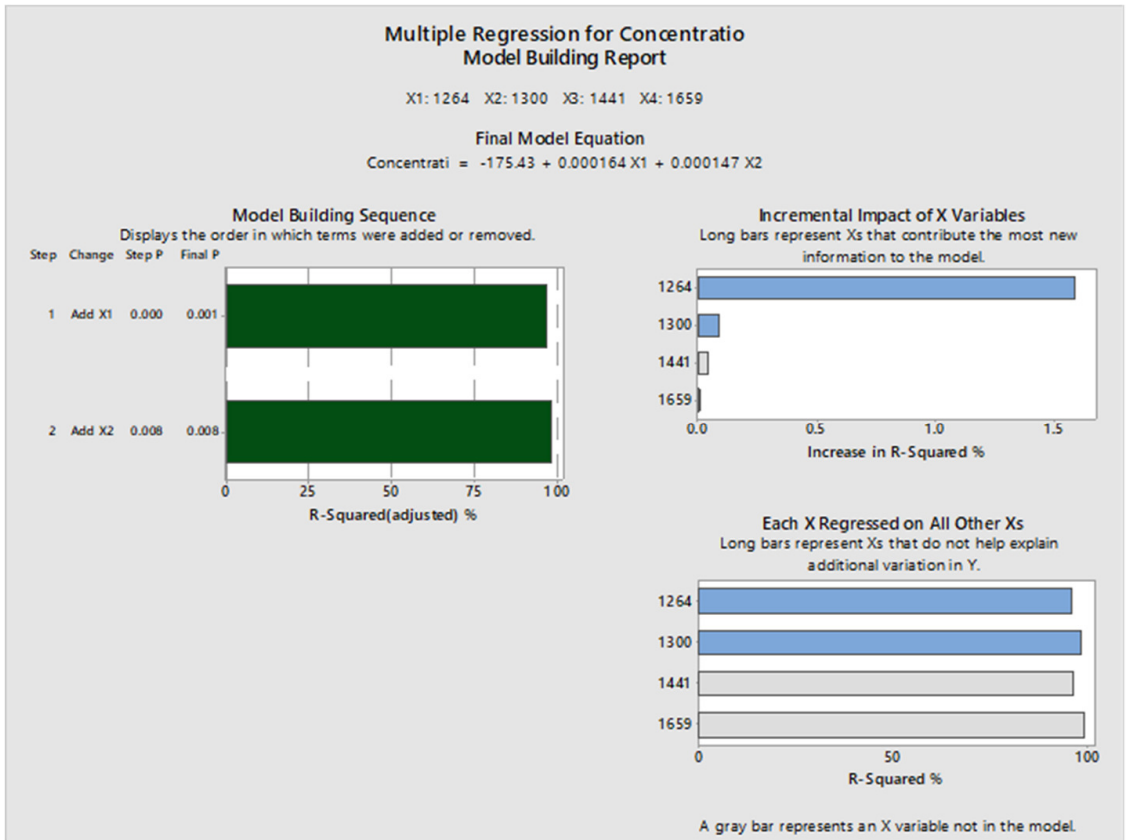

Figure 5. Model building report for adulteration of walnut oil

\section{PLS for the pumpkin oil}

Analysis of variance was applied on the data obtained for the pumpkin oil. The results are presented in Table 6.

Table 6. Analysis of variance

\begin{tabular}{|c|c|c|c|c|c|}
\hline Source & DF & Adj SS & Adj MS & F-Value & P-Value \\
\hline Regression & 4 & 3314.67 & 828.667 & 444.01 & 0.000 \\
\hline$\sim 1264 \mathrm{~cm}^{-1}$ & 1 & 73.16 & 73.161 & 39.20 & 0.000 \\
\hline$\sim 1300 \mathrm{~cm}^{-1}$ & 1 & 2.28 & 2.279 & 1.22 & 0.295 \\
\hline$\sim 1441 \mathrm{~cm}^{-1}$ & 1 & 0.92 & 0.919 & 0.49 & 0.499 \\
\hline$\sim 1659 \mathrm{~cm}^{-1}$ & 1 & 2.52 & 2.516 & 1.35 & 0.273 \\
\hline Error & 10 & 18.66 & 1.866 & & \\
\hline Total & 14 & 3333.33 & & & \\
\hline
\end{tabular}

For $\sim 1300 \mathrm{~cm}^{-} 1, \sim 1441 \mathrm{~cm}^{-1}$ and $\sim 1659 \mathrm{~cm}^{-1}$ the $\mathrm{p}$-value is high which means that they have little impact. For $\sim 1264$ $\mathrm{cm}^{-1}$ the $\mathrm{p}$-values is 0.000 which means that this factor has a very important impact.

In order to verify the model the R-sq was calculated (Table 7).

Table 7. Model summary

\begin{tabular}{|c|c|c|c|}
\hline S & R-sq & R-sq (ad) & R-sq (pred) \\
\hline 1.36614 & $99.44 \%$ & $99.22 \%$ & $98.64 \%$ \\
\hline
\end{tabular}

The R-sq predicted for pumpkin oils has a value of $98.64 \%$.

The regression equations for the adulteration of pumpkin oils are: Concentration $(\%)=$ $-163+0.000169 \cdot X 1+0.000081 \cdot X 2+0.000023 \cdot X 3-0.000027 \cdot X 4$

where:

$\mathrm{X} 1$ - peak area at $\sim 1264 \mathrm{~cm}^{-1}$

$\mathrm{X} 2$ - peak area at $\sim 1300 \mathrm{~cm}^{-1}$

$\mathrm{X} 3$ - peak area at $\sim 1441 \mathrm{~cm}^{-1}$ 
$\mathrm{X} 4$ - peak area at $\sim 1659 \mathrm{~cm}^{-1}$

Figure 6 shows residual normal plot for the Raman analysis obtained for pumpkin oil. The points follow a straight line which prove that there are no unusual observations.

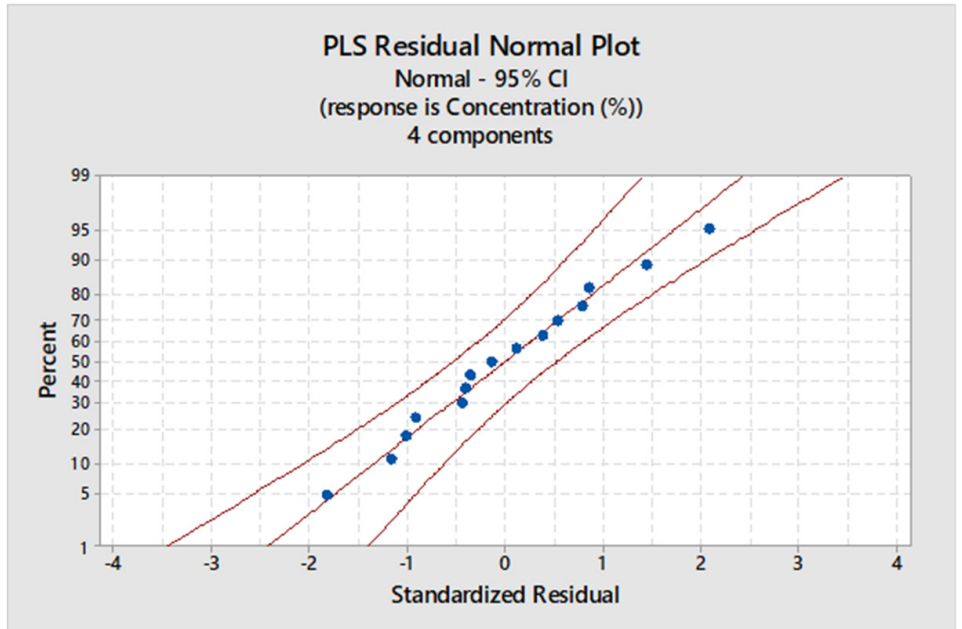

Figure 6. PLS residual for pumpkin oil

The correlation between the different variables on the adulteration of pumpkin oil is presented in Figure 7.

There is a negative correlation on the adulteration concentration for all 4 peaks $\left(\sim 1264 \mathrm{~cm}^{-1}, \sim 1300\right.$ $\mathrm{cm}^{-1}, \sim 1441 \mathrm{~cm}^{-1}$ and $\sim 1659 \mathrm{~cm}^{-1}$ ).

The final model equation does not contain all variables because the p-value has proven that some of them are not relevant. Figure 8 shows that peak at $\sim 1264 \mathrm{~cm}^{-1}$ has the highest impact while peaks at $\sim 1300$ $\mathrm{cm}^{-1}, \sim 1441 \mathrm{~cm}^{-1}$ and $\sim 1659 \mathrm{~cm}^{-1}$ do not help explain additional variation of the adulteration concentration.

The final model equation is:

Wallnot oil adulteration $\%=1090.4-0.002245 \cdot X 1$ (4)

where: X1 - area of the peak at $\sim 1264 \mathrm{~cm}^{-1}$.

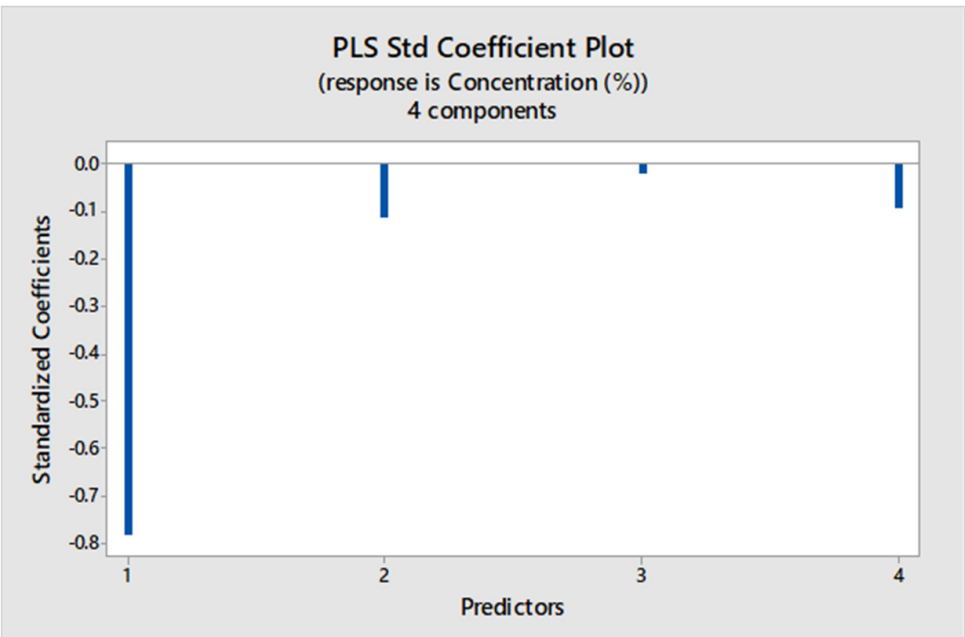

Figure 7. Projected scatterplot of the unstandardized regression coefficients for the adulteration of pumpkin oils 


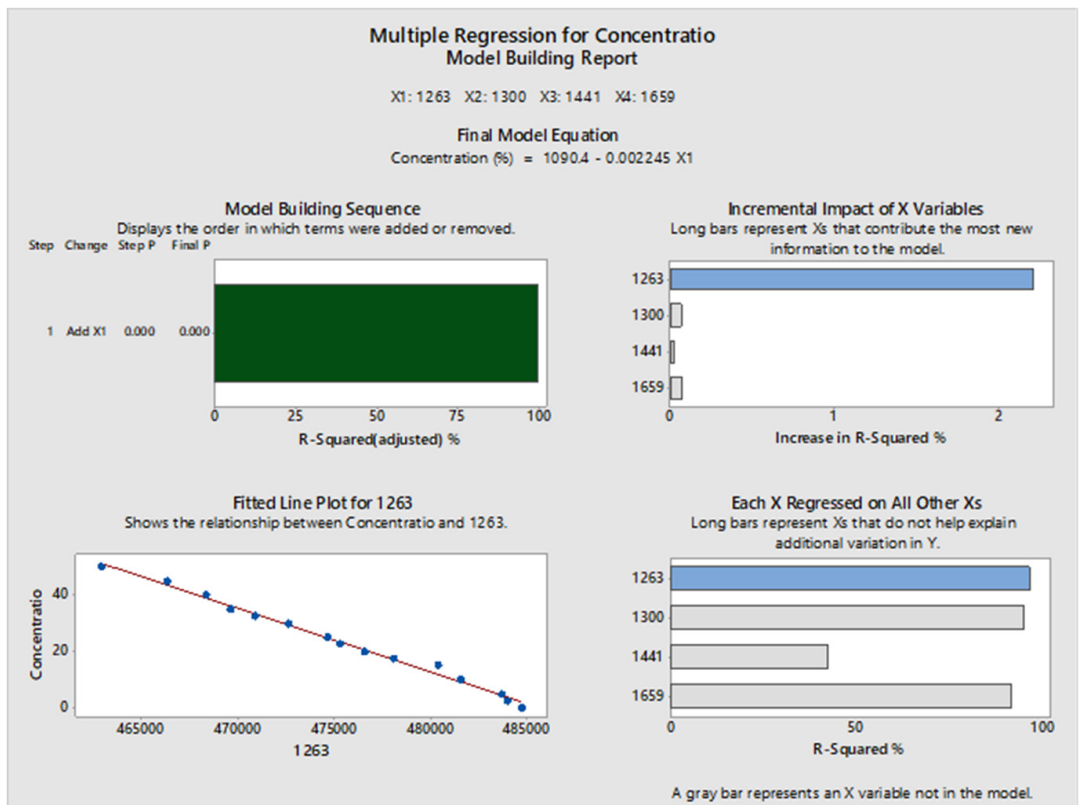

Figure 8. Model building report for the adulteration of pumpkin oil

In order to use the equation for the prediction of adulterated oils, the degree of prediction must be $\geq 95$ $\%$. The final prediction equation was tested for each oil type to see if it can correctly predict the percentage of adulteration. The obtained results are presented in Table 8.

Table 8. Prediction equation for different oils samples

\begin{tabular}{|c|c|c|c|c|c|}
\hline No. & $\begin{array}{l}\text { Sample } \\
\text { type }\end{array}$ & $\begin{array}{c}\text { Adulteration } \\
(\%)\end{array}$ & $\begin{array}{c}\text { Predicted value } \\
\text { (\%) }\end{array}$ & $\begin{array}{c}\text { The degree of adulteration } \\
\text { prediction }(\%)\end{array}$ & Remarks \\
\hline 1. & \multirow{4}{*}{ Walnut oil } & 5 & 4.8 & 96.0 & Meets the criteria \\
\hline 2. & & 10 & 10.1 & 99.0 & Meets the criteria \\
\hline 3. & & 15 & 15.4 & 97.3 & Meets the criteria \\
\hline 4. & & 30 & 30.2 & 99.3 & Meets the criteria \\
\hline 5. & \multirow{4}{*}{$\begin{array}{l}\text { Pumpkin } \\
\text { oil }\end{array}$} & 5 & 5.2 & 96.0 & Meets the criteria \\
\hline 6. & & 10 & 10.5 & 95.0 & Meets the criteria \\
\hline 7. & & 15 & 15.2 & 98.7 & Meets the criteria \\
\hline 8. & & 30 & 30.7 & 97.7 & Meets the criteria \\
\hline
\end{tabular}

\section{Discussion and conclusions}

A Raman portable spectrometer, which allows quick measurements on-site, was used to verify its sensitivity for testing the adulteration of walnut and pumpkin oils with sunflower oil. Different levels of concentration of sunflower oil, ranging from 2.5 to $50 \%$, were used to obtain adulterated samples. Four peaks of Raman spectra were selected, based on literature (Velioglu et al., 2016; Wei et al., 2013; Meenu et al., 2019; Li et al., 2018). These peaks situated at $\sim 1264 \mathrm{~cm}^{-1}, \sim 1300 \mathrm{~cm}^{-1}, \sim 1441 \mathrm{~cm}^{-1}$ and $\sim 1659 \mathrm{~cm}^{-1}$ were slowly modified with the increase of the degree of adulteration. These changes were quantified by the calculation and graphical representation of Raman peak areas. In order to obtain complex data from Raman spectra, a PLS statistic method was used to develop a prediction equation. An equation model was obtained for each type of studied oil with a prediction degree $\geq 95 \%$. In the literature there are few studies available on adulteration of walnut and pumpkin oils using Raman spectroscopy but the data obtained were in good agreement with similar studies performed on other types of vegetal oils (Aykas et al., 2019; Mendes et al., 2015). These results confirm 
that the Raman technique can be easily and successfully used in predicting the adulteration of pumpkin and walnut oils.

\section{Acknowledgements}

This research was funded by the Romanian Ministry of Research and Innovation, CCCDI-UEFISCDI, project number-18N/08.02.2019/PNCDI III, grant PROINSTITUTIO - Contract no.19PFE/17.10. and contract no.152 / 25.11.21016 POC-A.1-A.1.1.1-F-2015.

\section{Conflict of Interests}

The authors declare that there are no conflicts of interest related to this article. The authors read and approved the final manuscript.

\section{References}

Abbas O, Baeten V (2016). Advances in the identification of adulterated vegetable oils. In: Downey G (Ed). Advances in Food Authenticity Testing. Woodhead Publishing (1st ed), Duxford, United Kingdom pp 519-542.

Abou-Zeid SM, AbuBakr HO, Mohamed MA, El-Bahrawyd A (2018). Ameliorative effect of pumpkin seed oil against emamectin induced toxicity in mice. Biomedicine \& Pharmacotherapy 98:242-251. https://doi.org/10.1016/j.biopha.2017.12.040

Aykas DP, Karaman AD, Keser B, Rodriguez-Saona L (2020). Non-targeted authentication approach for extra virgin olive oil. Foods 9:221. https://doi.org/10.3390/foods9020221

Azadmard-Damirchi S, Torbati M (2015). Adulterations in some edible oils and fats and their detection methods. Journal of Food Quality and Hazards Control 2:38-44.

Breslow JL (2006). N-3 fatty acids and cardiovascular disease. The American Journal of Clinical Nutrition 83:S1477S1482. https://doi.org/10.1093/ajcn/83.6.1477S

Chen B, Tian P, Lu DL, Zhou ZQ, Shao ML (2012). Feasibility study of discriminating edible vegetable oils by 2D NIR, Analytical Methods 4:4310-4315. https://doi.org/10.1039/C2A Y25962A

Conlon LE, King RD, Moran NE, Erdman Jr. JW (2012). Coconut oil enhances tomato carotenoid tissue accumulation compared to safflower oil in the Mongolian gerbil (Meriones unguiculatus). Journal of Agricultural and Food Chemistry 60:8386-8394. https://doi.org/10.1021/jf301902k

Dodge Y (2008). The concise encyclopaedia of statistics. Springer-Verlag New York, pp 493-537.

Elfiky SA, Elelaimy IA, Hassan AM, Ibrahim HM, Elsayad RI (2012). Protective effect of pumpkin seed oil against genotoxicity induced by azathioprine The Journal of Basic \& Applied Zoology 65:289-298. https://doi.org/10.1016/j.jobaz.2012.10.010

Farres S, Srata L, Fethi F, Kadaoui A (2019). Argan oil authentication using visible/near infrared spectroscopy combined to chemometrics tools. Vibrational Spectroscopy 102:79-84. https://doi.org/10.1016/j.vibspec.2019.04.003

Fawzy EI, El Makawy AI, El-Bamby MM, Elhamalawy HO (2018). Improved effect of pumpkin seed oil against the bisphenol-A adverse effects in male mice. Toxicology Reports 5:857-863. https://doi.org/10.1016/j.toxrep.2018.08.014

Food and Agriculture Organization of the United Nations FAOSTAT (2004). Inventory of walnut research, germplasm and references. Retrieved 2020 April 30 from http://www.fao.org/3/y5704e/y5704e03.htm\#TopOfPage

Hammond EW (2003). Vegetable oils. In: Caballero B, Finglas P, Toldra F (Eds). Encyclopedia of Food Sciences and Nutrition. Academic Press (2nd ed), London, United Kingdom pp 5899-5904.

Hatzakis E (2013). Quality assessment and authentication of virgin olive oil by NMR spectroscopy: a critical review. Analytica Chimica Acta 765:1-27. https://doi.org/10.1016/j.aca.2012.12.003 
Hornstra G, Al MDM, Houwelingen ACV, Foreman-van Drongelen MMHP (1995). Essential fatty acids in pregnancy and early human development. European Journal of Obstetrics \& Gynecology and Reproductive Biology 61:157162. https://doi.org/10.1016/0028-2243(95)02153-J

Kumar A, Sharma A, Upadhyaya KC (2016). Vegetable oil: nutritional and industrial perspective. Current Genomics 17:230-240. https://doi.org/10.2174/1389202917666160202220107

Li B, Wang H, Zhao Q, Ouyang J, Wu Y (2015). Rapid detection of authenticity and adulteration of walnut oil by FTIR and fluorescence spectroscopy: A comparative study. Food Chemistry 181:25-30. https://doi.org/10.1016/j.foodchem.2015.02.079

Li Y, Fang T, Zhu S, Huang F, Chen Z, Wang Y (2018). Detection of olive oil adulteration with waste cooking oil via Raman spectroscopy combined with iPLS and SiPLS. Spectrochimica Acta Part A: Molecular and Biomolecular Spectroscopy 189:37-43. https://doi.org/10.1016/j.saa.2017.06.049

Man YBC, Rohman A, Mansor T (2011). Differentiation of lard from other edible fats and oils by means of Fourier transform infrared spectroscopy and chemometrics. Journal of the American Oil Chemists' Society 88:187-192. https://doi.org/10.1007/s11746-010-1659-x

Man YBC, Rohman A (2013). Analysis of canola oil in virgin coconut oil using FTIR spectroscopy and chemometrics. Journal of Food and Pharmaceutical Sciences 1:5-9. https://doi.org/10.14499/jfps

Martínez ML, Labuckas DO, Lamarque AL, Maestri DM (2010). Walnut (Juglans regia L.): Genetic resources, chemistry, by-products. Journal of the Science of Food and Agriculture 90:1959-1967. https://doi.org/10.1002/jsfa.4059

McMathis J (2015). Ancient pottery unearthed in Israel contains 8000-year-old olive oil. Israel Journal of Plant Sciences 62:65-74.

Meenu M, Cai Q, Xu B (2019). A critical review on analytical techniques to detect adulteration of extra virgin olive oil. Trends in Food Science \& Technology 91:391-408. https://doi.org/10.1016/j.tifs.2019.07.045

Mendes TO, da Rocha RA, Porto BLS, de Oliveira MAL, dos Anjos VDC, Bell MJ (2015). Quantification of extra-virgin olive oil adulteration with soybean oil: a comparative study of NIR, MIR, and Raman spectroscopy associated with chemometric Approaches. Food Analytical Methods 8:2339-2346. https://doi.org/10.1007/s12161-015$0121-y$

Minitab (2020). Example of getting and interpreting a p-value. Retrieved $202014^{\text {th }}$ July from https://support. minitab.com/en-us/minitab/18/help-and-how-to/statistics/basic-statistics/supporting-topics/basics/exampleof-getting-and-interpreting-a-p-value/

Minitab (2020). Model summary table for Fit General Linear Model. Retrieved $202011^{\text {th }}$ July from https://support.minitab.com/en-us/minitab/18/help-and-how-to/modeling-statistics/anova/how-to/fitgeneral-linear-model/interpret-the-results/all-statistics-and-graphs/model-summary-table/

Nam YS, Noh KC, Roh EJ, Keum G, Lee Y, Lee KB (2014). Determination of edible vegetable oil adulterants in sesame oil using $1 \mathrm{~h}$ nuclear magnetic resonance spectroscopy. Analytical Letters 47:1190-1200. https://doi.org/10.1080/00032719.2013.865199

Nederal S, Petrovic M, Vincek D, Pukec D, Skevin D, Kraljic K, Obranovic M (2014). Variance of quality parameters and fatty acid composition in pumpkin seed oil during three crop seasons. Industrial Crops and Products 60:15-21. https://doi.org/10.1016/j.indcrop.2014.05.044

Negi AS, Luqman S, Srivastava S, Krishna V, Gupta N, Darokar MP (2011). Antiproliferative and antioxidant activities of Juglans regia fruit extracts. Pharmaceutical Biology 49:669-673. https://doi.org/10.3109/13880209.2010.537666

Nishimura M, Ohkawara T, Sato H, Takeda H, Nishihira J (2014). Pumpkin seed oil extracted from Cucurbita maxima improves urinary disorder in human overactive bladder. Journal of Traditional and Complementary Medicine 4:72-74. https://doi.org/10.4103/2225-4110.124355

Parker T, Limer E, Watson AD, Defernez M, Williamson D, Kemsley EK (2014). 60 MHz 1 H NMR spectroscopy for the analysis of edible oils. TrAC Trends in Analytical Chemistry 57:147-158. https://doi.org/10.1016/j.trac.2014.02.006

Rabadán A, Pardo JE, Gómez R, Álvarez-Ortí M (2018). Evaluation of physical parameters of walnut and walnut products obtained by cold pressing. LWT 91:308-314. https://doi.org/10.1016/j.lwt.2018.01.061

Roccisano D, Kumaratilake J, Saniotis A, Henneberg M (2016). Dietary fats and oils: some evolutionary and historical perspectives concerning edible lipids for human consumption. Food and Nutrition Sciences 7:689-702. https://doi.org/10.4236/fns.2016.78070 
Seif HAS (2014). Ameliorative effect of pumpkin oil (Cucurbita pepo L.) against alcohol-induced hepatotoxicity and oxidative stress in albino rats. Beni-Suef University Journal of Basic and Applied Sciences 3:178-185. https://doi.org/10.1016/j.bjbas.2014.08.001

Shi T, Zhu MT, Chen Y, Yan XL, Chen Q, Wu XL, Lin J, Xie M (2018). 1H NMR combined with chemometrics for the rapid detection of adulteration in camellia oils. Food Chemistry 242:308-315. https://doi.org/10.1016/j.foodchem.2017.09.061

Soyinfo Center (2007). History of soybean crushing: soy oil and soybean meal-Part 1. Retrieved 2020 February 10 from https://www.soyinfocenter.com/HSS/soybean_crushingl.php

Statista (2020). Vegetable oil production worldwide 2000-2020. Retrieved 2020 March 25 from https://www.statista.com/statistics/263978/global-vegetable-oil-production-since-2000-2001/

Statista (2020). Vegetable oils: global consumption by oil type 2013/14 to 2019/2020. Retrieved 2020 February 12 from https://www.statista.com/statistics/263937/vegetable-oils-global-consumption/

Statsdirect (2020). P Values. Retrieved 2020 August 17 from https://www.statsdirect.com/help/basics/p_values.htm

Velioglu SD, Ercioglu E, Temiz HT, Velioglu HM, Topcu A, Boyaci IH (2016). Raman spectroscopic barcode use for differentiation of vegetable oils and determination of their major fatty acid composition. Journal of the American Oil Chemists' Society 93:627-635. https://doi.org/10.1007/s11746-016-2808-7

Wei D, Zhang YQ, Zhang B, Wang XP (2013). Rapid prediction of fatty acid composition of vegetable oil by Raman spectroscopy coupled with least squares support vector machines. Journal of Raman Spectroscopy 44:1739-1745. https://doi.org/10.1002/jrs.4386

Wong A, Viola D, Bergen D, Caulfield E, Mehrabani J, Figueroa A (2019). The effects of pumpkin seed oil supplementation on arterial hemodynamics, stiffness and cardiac autonomic function in postmenopausal women. Complementary Therapies in Clinical Practice 37:23-26. https://doi.org/10.1016/j.ctcp.2019.08.003

Yuan Z, Zhang L, Wang D, Jiang J, B. Harrington P, Mao J, Zhang Q, Li P (2020). Detection of flaxseed oil multiple adulteration by near-infrared spectroscopy and nonlinear one class partial least squares discriminant analysis, LWT 125:109247. https://doi.org/10.1016/j.lwt.2020.109247
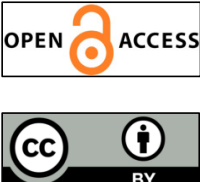

The journal offers free, immediate, and unrestricted access to peer-reviewed research and scholarly work. Users are allowed to read, download, copy, distribute, print, search, or link to the full texts of the articles, or use them for any other lawful purpose, without asking prior permission from the publisher or the author.

License - Articles published in Notulae Botanicae Horti Agrobotanici Cluj-Napoca are Open-Access, distributed under the terms and conditions of the Creative Commons Attribution (CC BY 4.0) License. (C) Articles by the authors; UASVM, Cluj-Napoca, Romania. The journal allows the author(s) to hold the copyright/to retain publishing rights without restriction. 